\title{
Olfactory Receptor Neuron
}

National Cancer Institute

\section{Source}

National Cancer Institute. Olfactory Receptor Neuron. NCI Thesaurus. Code C12633.

A bipolar neuron located in the sensory epithelium within the nasal cavity that detects odor signal molecules and transmits olfactory information to the central nervous system. 